\title{
Sero-epidemiology and associated risk factors of brucellosis among sheep and goat population in the south western Nepal: a comparative study
}

Tulsi Ram Gompo ${ }^{1 *}$ (D) Rubina Shah², Ishwari Tiwari ${ }^{2}$ and Yam Bahadur Gurung ${ }^{2}$

\begin{abstract}
Background: Brucellosis is a zoonotic disease caused by Brucella spp. In Nepal, the presence of brucellosis in small ruminants, namely sheep and goats, has impacted farmers' livelihood and the food safety of consumers. A crosssectional study was conducted in Rupandehi district of Nepal during January to March 2020 to investigate the seroepidemiology and associated risk factors of brucellosis in the sheep and goat population. Altogether, 19 sheep and 60 goat farms in the district were visited. Owners were interviewed to get information on animals, including their management and movement patterns. Three hundred fifty-seven samples (80 sheep and 277 goat samples) were collected proportionately based on farm sizes. Each serum sample was tested with Rose Bengal Test and ELISA to estimate the seropositivity of brucellosis. Logistic regression was carried out to calculate corresponding odds ratios of each variable associated with detection of brucellosis.
\end{abstract}

Results: At the farm level, 31.6\% (6/19; 95\% Cl: 12, 54\%) of sheep farms and 3.3\% (2/60, 95\% Cl: 0.9, 11.4\%) of goat farms were seropositive to brucellosis. Out of 80 sheep serum samples, 12 (15\%; 95\% Cl: 8.79-24.41\%) and out of 277 goat serum samples, three $(1.1 \%$; $95 \% \mathrm{Cl}$ : $0.37-3.14 \%)$ were seropositive to brucellosis. Age greater than 1.5 years $(\mathrm{OR}=5.56,95 \% \mathrm{Cl}: 1.39,29.38 ; p=0.02)$ and herd size of greater than $100(\mathrm{OR}=4.74,95 \% \mathrm{Cl}$ : $1.23,20.32, p=0.03$ ) were identified as significant risk factors for seropositivity of brucellosis in the sheep population. While in the goat population, none of the variables was identified as a significant risk factor.

Conclusion: The study provides evidence that the older sheep and the sheep from the large herds were at higher risk of brucellosis. A control program should be put in place immediately in the sheep population because they may transmit infections to other livestock as they were regularly moved for grazing and selling purposes. Also, strict biosecurity measures should be implemented among pastoralists to prevent brucellosis transmission in them. We suggest further one health-based study to reveal the transmission dynamics of brucellosis between animals and humans.

Keywords: Brucellosis, Zoonotic disease, Nepal, Sheep and goat, Livelihood, Risk factors, One health approach

\footnotetext{
*Correspondence: tulsigompo@gmail.com; tulsigompo@yahoo.com

${ }^{1}$ Central Veterinary Laboratory, Kathmandu, Nepal

Full list of author information is available at the end of the article
}

(c) The Author(s). 2021 Open Access This article is licensed under a Creative Commons Attribution 4.0 International License, which permits use, sharing, adaptation, distribution and reproduction in any medium or format, as long as you give appropriate credit to the original author(s) and the source, provide a link to the Creative Commons licence, and indicate if changes were made. The images or other third party material in this article are included in the article's Creative Commons licence, unless indicated otherwise in a credit line to the material. If material is not included in the article's Creative Commons licence and your intended use is not permitted by statutory regulation or exceeds the permitted use, you will need to obtain permission directly from the copyright holder. To view a copy of this licence, visit http://creativecommons.org/licenses/by/4.0/. The Creative Commons Public Domain Dedication waiver (http://creativecommons.org/publicdomain/zero/1.0/) applies to the data made available in this article, unless otherwise stated in a credit line to the data. 


\section{Background}

Brucellosis is an economically important zoonotic disease caused by the gram-negative bacteria of Brucella species [1-3]. People contract Brucellosis by the consumption of unpasteurized dairy products, undercooked meat [4-6], occupational exposures through handling of aborted fetus or placenta of infected animals [4], and inhalation of contaminated aerosol during the processing of the animal products $[4,5,7]$. Brucellosis creates significant economic losses to the livestock industry worldwide because it usually results in abortion, infertility, and decreased milk and meat production. The disease has been successfully managed or eradicated from several developed countries, but it is still endemic in livestock and human populations in resource-poor countries [8].

Ruminants are highly susceptible to brucellosis compared to other domestic animals [9]. Brucellosis in small ruminants is largely caused by $B$. melitensis and $B$. abortus, with clinical manifestations such as abortion, retention of placenta, infertility, epididymitis and sometimes arthritis [10]. In small ruminants, mainly goats and sheep, the infected animals remain as the primary transmission source to their herds. Most Brucella species, except $B$. ovis, are considered pathogenic to humans as they carry a surface antigen of smooth lipopolysaccharide (S-LPS) involved in the virulence of these bacteria $[11,12]$.

Small ruminants are important contributors to the livelihood of Nepalese farmers and goat, in particular, is considered as the "poor man's cow" [13, 14]. They are one of the principal commodities of the livestock production system in Nepal. There is an estimated population of 11 million goats and 0.8 million sheep in Nepal [15].

Nepalese sheep support the local carpet industry [16], while goat meat provides the second (20.36\%) most substantial volume of meat for consumption after buffalo meat (54.34\%) in Nepal [15]. The demand of goat meat is the highest during September to November every year, as the two biggest festivals, viz. Dashain and Tihar, fall within this period [17]. Import and rapid movement of small ruminants during festival seasons [18-20], potentially pose the highest risk of livestock disease transmission between the ruminant populations. There may also be an increased public health risk from diseases like brucellosis when people choose to slaughter goats and sheep at their homes for the festivals [21, 22]. Another risk associated with the infected sheep and goat flocks relates to the transhumant or nomadic form of migration, where livestock and pastoralist movement occurs between mountain pastures in warm seasons and lower altitudes the rest of the year. These activities increase the risk of disease transmission between livestock and humans [23].
Although there are some published studies describing the seroprevalence of animal and human brucellosis in Nepal [24-26], there are no studies that describe the risk factors related to animal brucellosis in Nepal. Identifying risk factors and implementing prevention and control programs could lead to a decrease in the disease burden in small ruminants, with consequent improvements in human health. We aimed to describe the comparative seroprevalence and risk factors of goat and sheep brucellosis together, as they are generally found in contiguous herds or mixed farming systems. Effective control and preventive measures can be applied once the risk factors are identified.

\section{Methods \\ Study sites}

This study was conducted in Rupandehi district in the southwestern region of Nepal (Fig. 1, created using QGIS). According to Livestock Statistics Report of Nepal (2017), the population of goat and sheep in Rupandehi were 185,332 and 4024, respectively [16]. This district was selected for study because it shares the border with northern India from where goats are imported into Nepal [27]. This brings an increased risk of disease introduction into the small ruminant population in Nepal. Informal livestock trade can even be more detrimental when the risk of disease introduction is concerned. Also, there is a risk of disease spread due to the internal movement of goats and sheep between other adjacent districts.

\section{Study design}

A cross-sectional study was conducted on the goat and sheep population of Rupandehi district between January to March 2020. Semi-structured questionnaire was administered to collect the information on each flock's animal characteristics, management status, and animal movement system. The survey was initially designed in English and later translated to the local Nepali language. Next, blood samples were collected during the time of interviewing the sheep and goat herd owners. Written consent from the owners was obtained during the questionnaire and sample collection processes.

\section{Sampling and sample size calculation}

A sampling frame was constructed to list all the registered goat and sheep farms in the district. There are 16 local levels in the Rupandehi district with 106 accessible commercial goat and sheep flocks [28]. The total number of the flock was calculated by assuming that the prevalence of the disease in the congregation was $50 \%$ at 


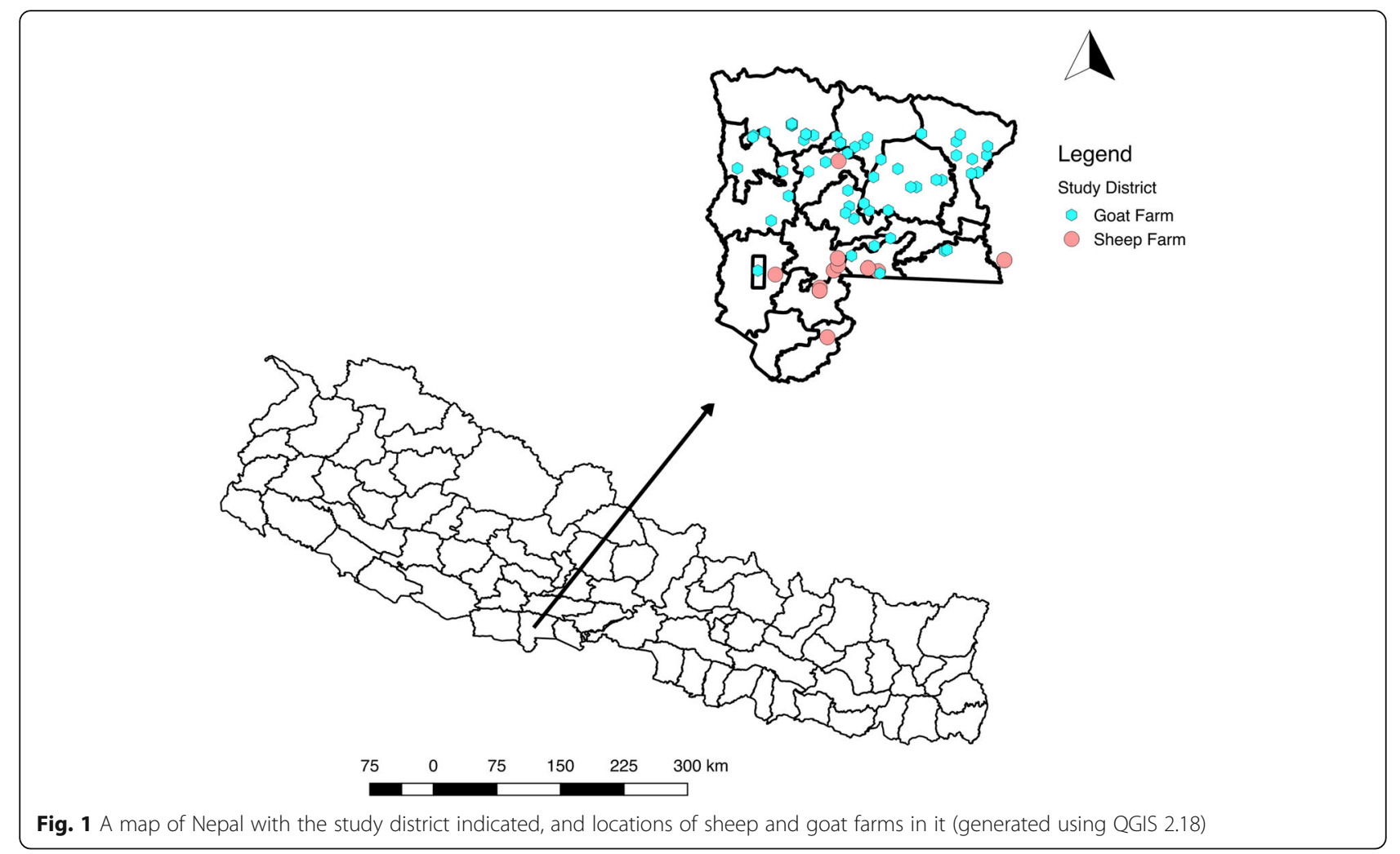

95\% confidence interval (CI) with 5\% desired precision by using the following formula (Eq. 1).

The formula is based on:

$$
\mathrm{N}=\frac{1.96^{2} \mathrm{P}_{\exp }\left(1-\mathrm{P}_{\exp }\right)}{\mathrm{d}^{2}}
$$

where $N=$ sample size, $\mathrm{P}_{\exp }=$ expected prevalence, and $\mathrm{d}=$ absolute precision [29].

The total number $(\mathrm{N})$ of the flocks to be selected by this method was 84 .

A total of 84 farms in the district were selected, but five farms did not agree to participate. Thus, samples were collected from 79 farms (60 goat farms and 19 sheep farms) only. In total, 357 sera samples (277 goat and 80 sheep samples) were collected for this study. The number of animals selected from each flock was based on their herd size. At least $5 \%$ of animals from each flock were sampled for the study.

\section{Laboratory analysis}

The collected samples were stored in an ice pack and transported to the laboratory for further analysis. A Rose Bengal plate test was performed as a screening test for brucellosis. All serum samples, including both Rose Bengal seropositive and seronegative samples, were tested by ELISA. All the tests were performed at Central
Veterinary Laboratory (CVL), the national veterinary reference laboratory.

\section{Rose Bengal test (RBT)}

Rose Bengal Antigen (ID vet, France) was used as a rapid test to screen for antibody to Brucella spp. with a published sensitivity of $87.2 \%$ [30] and specificity of $99.6 \%$ [31]. The test serum $(0.03 \mathrm{ml})$ was mixed with an equal volume of RBT antigen on a glass slide to produce a zone of approximately $2 \mathrm{~cm}$ in diameter. The mixture was agitated gently for 4 min at ambient temperature and then observed for agglutination. Tests were considered positive when any visible reaction or agglutination were observed.

\section{ELISA (enzyme-linked immunosorbent assay)}

The "ID Screen" Brucellosis Serum Indirect Multispecies" i-ELISA kit (ID vet France, kit reference BRUS-MS-5P) was used to test sera. The kit detects antibodies to various species of smooth lipopolysaccharide (S-LPS) expressing Brucella, such as $B$. abortus, B. mellitensis, and B. suis. The sensitivity and specificity of this test were 96.8 and $96.3 \%$, respectively, according to the Bayesian estimation approach [32]. All the testing procedures were performed according to the protocols provided by the manufacturer. The test plates were read under the ELISA 
reader ("Multiskan ${ }^{\text {tw }}$ FC Microplate Photometer") at an optical density (OD) $450 \mathrm{~nm}$ within $15 \mathrm{~min}$.

\section{Data management and statistical analysis}

The raw data collected from the paper-based questionnaire was manually entered on the MS Excel spreadsheet and converted to CSV files. The data was analyzed using open-source epidemiological software Open epi and R version 3.6.1 [33]. The descriptive data analysis was performed to investigate the population characteristics of both the species.

Sheep and goat individual and flock-level prevalence were calculated to estimate the overall species-wise disease prevalence in the district. The RBT and ELISA were interpreted in parallel such that an individual or flock was considered seropositive if they tested positive to either test. For instance, an animal tested positive by either RBT or i-ELISA was considered a positive animal. Any herd with at least an animal tested seropositive to either RBT or I-ELISA was deemed positive flock. The chi-square test of associations and inter-test agreement between the Rose Bengal Test and ELISA tests for the seropositivity of brucellosis for sheep and goat were calculated [34, 35].

The Q-Q plot for the normality assessed the data distributions of each continuous variable. These continuous variables, such as flock size, age, and parity number, were converted into binary categorical variables using the quartile of distributions (e.g., median) to manage the problem of linearity [36].

Each of the independent factors was examined with the response variable (seropositivity) using contingency tables. Fisher's exact tests and chi-square tests (when appropriate) were used to examine associations between response variables and explanatory variables.

The empty or zero cells in the two by two table analyses were corrected by data modification methods by Argesti (2002) in Open epi to calculate corresponding odds ratios and $p$ values [37-39]. In this case, to rectify the effect of small-sample bias on maximum likelihood estimation of the logistic model, firth logistic regression was used by "logistif" function in $\mathrm{R}$ and firth logit option in STATA in multivariable regression analysis [37, 38, 40-43].

Chi-square test of association between categorical variables, such as median flock size, median age category and median parity category, were performed. As there was a significant association $(x 2=116.78, p<0.001)$ between the age and parity category was noted, the parity category was dropped from the model because age was a biologically plausible risk factor [44]. The variable's potential confounding effects were checked with the changes in the point estimates of the variables that remain in the model [34, 45]. Any changes in the coefficient with $>20 \%$ were included in the final model.

The potential risk factors with the significance level $p \leq 0.2$ following the bivariate analysis were manually entered in the final multivariable model [34]. A backward stepwise variable selection was used to add the variable with the lowest $p$-value to construct a final model with a significance level of $p \leq 0.05$. Any variables with $p$-value $<0.05$ at multivariable logistic regression analysis were considered statistically significant risk factors. The above process was performed separately for each set of risk factors of goat and sheep flock for the valid comparison. The fitness of the final model was assessed by Hosmer- Lemeshow goodness of fit test, and the model was fit $(p>0.05)$.

\section{Results}

\section{Descriptive study of animal population}

The study involved 60 (75.94\%) goat farms and 19 (24.1\%) sheep farms; from which, a total of 277 (77.59\%) goat samples and $80(22.41 \%)$ sheep blood samples were collected and tested for brucellosis. The median ages of goat and sheep populations were 1.5 years each, while the mean ages of goat and sheep population were $2.1 \pm$ 1.1 and $1.9 \pm 1.7$ years, respectively. The median flock sizes of the goat and sheep farms were 48 and 100, while the mean flock sizes were $66 \pm 11,93 \pm 4$, respectively. The characteristics of goat and sheep population are depicted in Table 1.

From the survey, $15 \%(12 / 80)$ of sheep were either purchased from nearby herds or brought from India, while $37.6 \%(104 / 277)$ of the goats were either collected from neighbouring districts or brought from abroad. About $90 \%$ of the goat herds included in the study were registered farms, but more than half of the sheep herds were not registered. Interestingly, an indigenous community mainly residing at the terai belt of south western Nepal maintained most sheep flocks, which was the primary means of their livelihoods.

\section{Seroprevalence of brucellosis in goat and sheep population}

The flock level prevalence for sheep and goat farms was $30 \%(6 / 19 ; 95 \%$ CI: $12,54 \%)$ and $3.33 \%(2 / 60,95 \%$ CI: $0.92,11.36 \%)$ respectively. Of the total of 80 sheep samples tested, 12 (15\%; 95\% CI: 8.79-24.41), and among 277 goat samples tested 3 (1.1\%; 95\% CI: 0.37-3.14) were seropositive to Brucella spp. (Table 2). There is a significant difference between the proportion of sheep and goat populations with seropositivity to brucellosis $\left(\mathrm{x}^{2}=29.78, p<0.001\right)$.

Antibodies to Brucella were detected only in female goats, but in the sheep populations, a higher proportion 
Table 1 Comparison of population characteristics for studied goat and sheep population

\begin{tabular}{|c|c|c|c|c|c|c|c|}
\hline \multirow[b]{2}{*}{ Species } & \multirow[b]{2}{*}{ Variables } & \multicolumn{6}{|c|}{ Descriptive statistics } \\
\hline & & Mean \pm SE & Min. & Q1 & Median & Q3 & Max. \\
\hline \multirow[t]{2}{*}{ Sheep $(n=80)$} & Age (years) & $1.9 \pm 1.7$ & 0.2 & 1 & 1.5 & 2.5 & 8 \\
\hline & Flock size & $93 \pm 4$ & 12 & 65 & 100 & 120 & 150 \\
\hline \multirow[t]{2}{*}{ Goat $(n=277)$} & Age (years) & $2.1 \pm 1.1$ & 0.2 & 1 & 2 & 2.5 & 13 \\
\hline & Flock size & $66 \pm 11$ & 20 & 30 & 48 & 60 & 550 \\
\hline
\end{tabular}

of males, $18.75 \%(3 / 16)$, were seropositive to Brucella than females, $14.1 \%(9 / 64)$. Only the local goat breeds, such as Khari, were seropositive to Brucella by ELISA. Lampuchhre is an indigenous sheep breed that had the highest burden of disease. The detailed illustrations of the sex-wise and breed-wise comparison of seroprevalence of Brucella among goats and sheep by both RBT and ELISA are described in Table 2.

There was a significant association $\left(x^{2}=28.29, p<\right.$ 0.001 ) between seropositivity of RBT and ELISA tests for brucellosis in sheep and goats [34] and an extremely high level of agreement between the tests $(\kappa=0.95,95 \%$ CI: $0.85-1, p<0.001)[35]$.

\section{Univariable regression analysis}

The bivariate analysis of the sheep and goat data was depicted in Tables 3 and 4, respectively. Sheep greater than 1.5 years of age had significantly higher odds of brucellosis (OR $=4.29,95 \% \mathrm{CI}: 1.16,20.63, p=0.0406)$ than the sheep of age $\leq 1.5$ years. There were significantly higher odds of brucellosis among sheep when flock size was $>100(\mathrm{OR}=4.2,95 \%$ CI: $1.19,15.91$, $p=0.026)$ than the sheep herds of $\leq 100$. Sheep that had parity greater than one were 4.11 more likely to be detected with brucellosis compared to sheep $\leq 1$, but the result was statistically borderline significant $(\mathrm{OR}=4.11,95 \% \mathrm{CI}: 0.98,21.29, p=0.055)$ (Table 3).

In bivariate analysis, the only variable associated with seropositivity was that the goats taken for grazing had significantly higher odds (OR $=14.5,95 \%$ CI: 1.1, 283.9, $p=0.003$ ) of Brucella seropositivity compared to goats stall-fed at farms (Table 4).

\section{Multivariable logistic regression analysis}

The variables that qualified from the sheep data for multivariable analysis $(p<0.20)$ were age, gender, grazing system and disinfection process applied at the farm entry point. Similarly, for the goat data, the same sets of the variables were qualified for final firth multivariable logistic regression analysis based on the cut-off criteria of $p<0.20$.

In the multivariable regression analysis, sheep of older age ( $>1.5$ years) had significantly higher odds (OR $=5.56,95 \%$ CI: 11.39, 29.38, $p=0.02)$ of Brucella seropositivity compared to the younger sheep $(\leq 1.5$ years) (Table 5). The sheep farms of flock size greater than 100 , had higher odds $(\mathrm{OR}=4.74,95 \% \mathrm{CI}: 1.23$, 20.32, $p=0.03$ ) of Brucella seropositivity than those of smaller farm size.

In the goat population, none of the variables was identified as statistically significant $(p<0.05)$ risk factors for brucellosis after running multivariable firth logistic regression (Table 6). Goats from the frequent grazing herds had higher odds (OR $=13.82,95 \% \mathrm{CI}$ : 0.70, 272.20) of Brucella seropositivity than the goats from isolated herds (Table 6), but this was borderline statistically significant $(p=0.08)$.

Table 2 Comparison of seroprevalence of Brucella among goats and sheep by sex and breed-wise classification

\begin{tabular}{|c|c|c|c|c|c|}
\hline Variables & Category & Total number (\%) & RBT positive (\%) & ELISA positive (\%) & Overall Prevalence $(95 \% \mathrm{Cl})$ \\
\hline Species & Sex & & & & \\
\hline \multirow[t]{2}{*}{ Goat } & Male & $65(23.46)$ & 0.00 & 0.00 & $1.1 \%(0.37-3.14)$ \\
\hline & Female & $212(76.53)$ & $2.36 \%(5 / 212)$ & $1.42 \%(3 / 212)$ & \\
\hline \multirow[t]{3}{*}{ Sheep } & Male & $16(20)$ & $18.75 \%(3 / 16)$ & $18.75 \%(3 / 16)$ & $15 \%(8.79-24.41)$ \\
\hline & Female & $64(80)$ & $12.5 \%(8 / 64)$ & $14.1 \%(9 / 64)$ & \\
\hline & Breeds & & & & \\
\hline \multirow[t]{2}{*}{ Goat* } & Local & $135(48.74)$ & $2.22 \%(3 / 135)$ & $2.22 \%(3 / 135)$ & $1.1 \%(0.37-3.14)$ \\
\hline & Exotic & $142(51.26)$ & $1.41 \%(2 / 142)$ & 0.00 & \\
\hline \multirow[t]{2}{*}{ Sheep } & Lampuchhre & $75(93.75)$ & $14.67 \%(11 / 75)$ & $16 \%(12 / 75)$ & $15 \%(8.79-24.41)$ \\
\hline & Baruwal & $5(6.25)$ & 0.0 & 0.00 & \\
\hline
\end{tabular}

* Exotic breeds of goat included Boer and Jamunapari. Local breeds of goat included Khari and Terai 
Table 3 Univariable analysis results of potential risk factors associated with sero-positivity of sheep population against Brucella spp.

\begin{tabular}{|c|c|c|c|c|c|c|}
\hline Determinants & Total no. of sheep & Brucella positive & Brucella negative & Odds ratio (OR) & $95 \% \mathrm{Cl}$ & $P$ value \\
\hline \multicolumn{7}{|l|}{ Animal Origin } \\
\hline Purchased & 12 & 3 & 9 & 2.19 & $(0.85,2.21)$ & 0.32 \\
\hline Homebred & 68 & 9 & 59 & Ref & & \\
\hline \multicolumn{7}{|c|}{ Age $($ median $=1.5$ years $)$} \\
\hline$>1.5$ & 37 & 9 & 28 & 4.29 & $(1.16,20.63)$ & $0.041^{*}$ \\
\hline$\leq 1.5$ & 43 & 3 & 40 & Ref & & \\
\hline \multicolumn{7}{|c|}{ Herd size $($ median $=100)$} \\
\hline$>100$ & 24 & 7 & 17 & 4.2 & $(1.19,15.91)$ & $0.026^{*}$ \\
\hline$\leq 100$ & 56 & 5 & 51 & Ref & & \\
\hline \multicolumn{7}{|c|}{ Parity (median $=1$ ) } \\
\hline$>1$ & 24 & 6 & 18 & 4.11 & $(0.98,21.29)$ & 0.055 \\
\hline$\leq 1$ & 40 & 3 & 37 & Ref & & \\
\hline \multicolumn{7}{|l|}{ Gender } \\
\hline Male & 16 & 3 & 13 & 1.41 & $(0.28,5.53)$ & 0.646 \\
\hline Female & 64 & 9 & 55 & Ref & & \\
\hline \multicolumn{7}{|l|}{ Grazing } \\
\hline Yes & 74 & 12 & 62 & 2.6 & $(0.12,49.16)$ & 0.154 \\
\hline No & 6 & 0 & 6 & Ref & & \\
\hline \multicolumn{7}{|c|}{ Repeat breeding } \\
\hline Yes & 11 & 3 & 8 & 2.94 & $(0.62,2.63)$ & 0.199 \\
\hline No & 53 & 6 & 47 & Ref & & \\
\hline
\end{tabular}

${ }^{*} P$ value $<0.05$ means statistically significant

\section{Discussion}

\section{Seroprevalence of brucellosis between sheep and goats}

We conducted a comparative study on the epidemiology of Brucella among goat and sheep herds in Rupandehi district. The burden of brucellosis was higher among the sheep, $15 \%$ (95\% CI: 8.79-24.41), compared to goats, $1.1 \%$ (95\% CI: 0.37-3.14). A seasonal study [46] estimated that $6.6 \%(n=212)$ of sheep and $3.4 \%(n=774)$ of goats from various districts of Nepal were seropositive by indirect multispecies ELISA. It also determined that the prevalence of brucellosis was higher in sheep than goats which supports the findings of the current study. This variation in seroprevalence between small ruminant species might be due to differences in the herding practices. In Nepal, a transhumant rotational sheep grazing system is used in many parts of the country. The seasonal migratory pattern of sheep could contribute to a higher rate of transmission in these animals [14]. This finding was also supported by a study conducted [44] in Tajikistan.

It has been suggested that goats are more susceptible to B. melitensis infection than sheep [47], but this might also reflect differences in the variation in geographical settings and differences between management of livestock production systems for sheep and goats. There were low numbers of seropositive goats in our research (3/227); however, if we had conducted our study from September to October, the prevalence of the disease would likely increase, due to the higher number of animal movements around this time for the ritual slaughter in Nepal. As none of the sheep and the goat flocks were vaccinated, the result of this study was evidence of natural infection transmission of brucellosis within the small ruminants in the study areas.

The prevalence of brucellosis in female sheep and goats were higher compared to that in males. This might be because the female sheep and goats will remain in the herd for a longer time as they are generally not slaughtered for meat, but retained for breeding in Nepal. Females are sold or exchanged between the flocks for kidding and they might have a higher risk for exposure to Brucella infected animals in the new environment, or they might bring the infection with them. Biologically, females are highly susceptible to Brucella spp. due to presence of erythritol in their gravid uterus [48].

\section{Significant risk factors}

This work describes the first brucellosis associated risk factors study in small ruminants in Nepal to the best of our knowledge. Brucellosis is one of the priority 
Table 4 Univariable analysis results of potential risk factors associated with sero-positivity of goat population against Brucella spp.

\begin{tabular}{|c|c|c|c|c|c|c|}
\hline Determinants & Total no of goats & Brucella Positive & Brucella Negative & Odds Ratios (OR) & $95 \% \mathrm{Cl}$ & $P$ value \\
\hline \multicolumn{7}{|l|}{ Animal Origin } \\
\hline Purchased & 105 & 2 & 103 & 1.2 & $0.11,26.11$ & 0.87 \\
\hline Homebred & 172 & 1 & 171 & Ref & & \\
\hline \multicolumn{7}{|c|}{ Age (median $=2$ years) } \\
\hline$\leq 2$ & 194 & 3 & 191 & 3.1 & $0.16,59.74$ & 0.12 \\
\hline$>2$ & 83 & 0 & 83 & Ref & & \\
\hline \multicolumn{7}{|c|}{ Herd size $($ median $=48)$} \\
\hline$\leq 48$ & 140 & 3 & 137 & 7 & $0.36,136.8$ & 0.06 \\
\hline$>48$ & 137 & 0 & 137 & Ref & & \\
\hline \multicolumn{7}{|c|}{ Parity (median $=1$ ) } \\
\hline$\leq 1$ & 113 & 3 & 110 & 6.5 & $0.33,127.2$ & $0.04^{*}$ \\
\hline$>1$ & 102 & 0 & 102 & Ref & & \\
\hline \multicolumn{7}{|l|}{ Gender } \\
\hline Female & 211 & 3 & 209 & 2.19 & $0.112,42.9$ & 0.34 \\
\hline Male & 65 & 0 & 65 & ref & & \\
\hline \multicolumn{7}{|l|}{ Grazing } \\
\hline Yes & 92 & 3 & 89 & 14.5 & $1.1,283.9$ & $0.01^{*}$ \\
\hline No & 185 & 0 & 185 & Ref & & \\
\hline \multicolumn{7}{|c|}{ Repeat breeding } \\
\hline Yes & 42 & 1 & 41 & 2.1 & $0.18,23.28$ & 0.29 \\
\hline No & 171 & 2 & 169 & Ref & & \\
\hline
\end{tabular}

${ }^{*} P$ value $<0.05$ means statistically significant

zoonoses of the Government of Nepal. There might be some differences between the local risk factors identified with those identified elsewhere, but effective disease management lies in localized ways of managing the diseases.

The sheep population of age greater than 1.5 years had significantly higher odds of Brucella seropositivity than the younger ones. It might be because the older sheep remained in the flock for a long time, and they had a longer duration of exposure [44]. It is supported by many other studies $[44,49]$ that reported that biologically younger animals were more resistant to infection than adult animals. Nevertheless, as we could not detect active infection status of brucellosis in sheep either by bacterial isolation or use of polymerase chain reaction
(PCR) in this study, the actual age-related risk factor was not determined.

Interestingly, age was not a significant risk factor for brucellosis in the goat population in the district. This may be because goat flocks were mainly maintained for meat production in Nepal, and most animals were sent to slaughter within a year.

The larger flock size $(>100)$ of sheep was another significant $(p=0.03)$ risk factor for brucellosis in this study. It is likely that the risk of disease transmission increased as the flock of sheep moved around in a large number of activities such as grazing. Also, the sheep flocks we visited were managed closer to one another such that the transmission of diseases between herds was more likely as they could mix up during grazing.

Table 5 Multivariable analysis results of risk factors $(p<0.05)$ associated with sero-positivity of sheep population against Brucella spp.

\begin{tabular}{llccccc}
\hline Determinants & Category & Coefficient & Standard Error & Odds ratio (OR & 95\% Cl & $(1.39,29.38)$ \\
\hline Age (median =1.5 years) & $>1.5$ & 1.72 & 0.76 & 5.56 & $0.02^{*}$ \\
& $\leq 1.5$ & & & 4.74 & $(1.23,20.32)$ \\
Herd size (median $=100)$ & $>100$ & 1.56 & 0.70 & & $0.03^{*}$ \\
& $\leq 100$ & & & & \\
\hline
\end{tabular}

*P value $<0.05$ means statistically significant 
Table 6 Multivariable analysis results of risk factors $(p<0.05)$ associated with sero-positivity of goat population against Brucella spp.

\begin{tabular}{|c|c|c|c|c|c|c|}
\hline Determinants & Category & Coefficient & Standard Error & Odds ratio (OR) & $95 \% \mathrm{Cl}$ & $P$ value \\
\hline \multirow[t]{2}{*}{ Age (median = 2 years) } & $>2$ & 0.98 & 1.54 & 2.24 & $(0.12,45.89)$ & 0.60 \\
\hline & $\leq 2$ & & & & & \\
\hline \multirow[t]{2}{*}{ Herd size $($ median = 48) } & $>48$ & 1.86 & 1.53 & 6.44 & $(0.32,128.16)$ & 0.22 \\
\hline & $\leq 48$ & & & & & \\
\hline \multirow[t]{2}{*}{ Grazing } & Yes & 2.63 & 1.52 & 13.82 & $(0.70,272.20)$ & $0.08^{a}$ \\
\hline & No & & & & & \\
\hline
\end{tabular}

a: This variable has borderline significant $p$-value and could be a potential risk factor

None of the variables related to the goats was significantly associated with Brucella antibody detection in the multivariable analysis. It might be due to the low prevalence of seropositive animals $(n=3 / 277)$ among goat population in the district. However, the difference in seroprevalence between grazing goats and stall-fed goats warrants further investigation. An additional complicating factor may be that while sheep and goat flocks were managed in geographically distinct areas, there was a higher probability of intermingling when taken for grazing in the pasture, watering points or animals moved to live markets.

Like other studies, our study had some limitations. The complement fixation test (CFT) for confirmation of brucellosis in sheep and goat populations was not performed as it was not available in the Central Veterinary Laboratory. Furthermore, B. ovis might be present in tested samples, but the diagnostic tests applied would not have picked it up due to low cross-reactivity of smooth LPS Brucella spp. Another limitation is that we could not address a detailed examination of the farmworker's occupational safety issues in this study.

The findings from this work provide better epidemiological insight that could be utilized to improve management of important diseases such as brucellosis in small ruminants in Nepal. Discovering such a substantial burden of brucellosis in small ruminants, mostly in sheep, asks for the development of more focused control strategies by the Department of Livestock Services (DLS), Nepal.

\section{Conclusion}

The estimation of disease burden and identifying risk factors associated with seropositivity of brucellosis in sheep and goat suggests that this disease is not evenly spread among small ruminants in Nepal. It is related to economic and occupational safety issues that needs to be considered when controlling brucellosis in Nepal. Increased age and larger flock sizes were the key risk factors for Brucella seropositivity among the sheep population. Grazing of goats may also be a risk factor in the goat population for Brucella seropositivity, and this needs to be investigated more thoroughly. Goats and sheep are valuable commodities for the livelihood of Nepalese farmers.

The prevention and control of brucellosis are crucial to the long term progress of this industry and for the safety of people who work with these animals. Brucellosis has been mentioned in the documents of the Government of Nepal as one of the priority zoonoses, but real-time disease surveillance and reporting are almost absent. This study could provide insights into the epidemiologic aspects of brucellosis in Nepal. However, we suggest further studies on the national level to get the bigger picture of animal brucellosis epidemiology in Nepal.

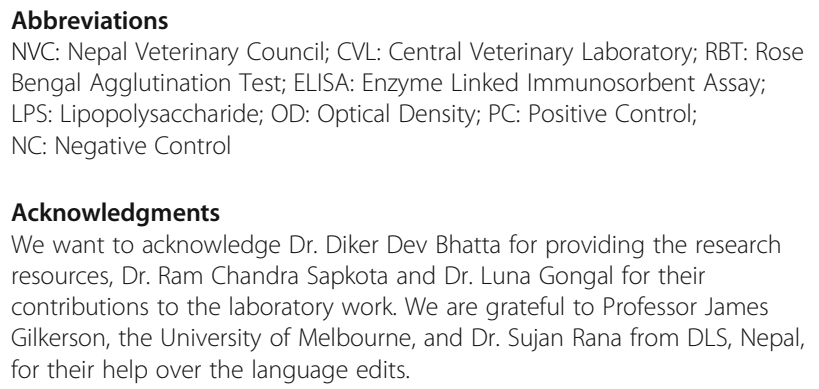

Availability of the data materials

The data for this project can be accessed from the personal data repository link: https://github.com/tulsiramgompo/sheep_and_goat_brucellosis

\section{Authors' contributions}

TRG: Conceived the original idea, perform lab tests, conducted data analysis, created the map by QGIS, wrote the initial draft, reviewed the final draft. RS: Conceived idea, collected samples and data, assisted in lab tests, assisted in literature review. IT: Assisted in sample collection and data recording. YBG: Supervision, reviewed initial and the final draft. All authors have read and approved the manuscript.

\section{Funding}

Authors received no special funding for this work.

\section{Declarations}

Ethics approval and consent to participate

An ethical statement for animal subjects was approved by the Nepal Veterinary Council (NVC), the veterinary statutory body in Nepal, with the Ref No. 279(TG)/2076-77. Written consent from the sheep and goat owners were obtained before the interview. Experienced veterinarians handled all the animals during sample collections taking into account minimal pain in the animals. The owners agreed to receive the test reports of their sheep and goat herds maintaining confidentiality. 


\section{Consent for publication}

Not applicable.

\section{Competing interests}

The authors declare that they have no competing interests.

\section{Author details}

${ }^{1}$ Central Veterinary Laboratory, Kathmandu, Nepal. ${ }^{2}$ Institute of Agriculture and Animal Science, Tribhuvan University, Paklihawa, Nepal.

\section{Received: 24 June 2020 Accepted: 14 March 2021}

Published online: 25 March 2021

\section{References}

1. Pappas G, Papadimitriou P, Akritidis N, Christou L, Tsianos EV. The new global map of human brucellosis. Lancet Infect Dis. 2006;6(2):91-9. https:// doi.org/10.1016/S1473-3099(06)70382-6.

2. Rossetti CA, Arenas-Gamboa AM, Maurizio E. Caprine brucellosis: a historically neglected disease with significant impact on public health. PLoS Negl Trop Dis. 2017;11(8):e0005692. https://doi.org/10.1371/journal.pntd. 0005692

3. Alton GG, Jones LM, Pietz DE. Laboratory techniques in brucellosis. Monogr Ser World Health Organ. 1975:1-163.

4. Corbel MJ. Brucellosis in human and animals. WHO, OIE and FAO; 2006.

5. Sammartino L.E., Gil A., Elzer P. Capacity building for surveillance and control of bovine and caprine brucellosis. Food and Agriculture Organisation; 2006. https://www.fao.org/3/a0083e/a0083e0a.htm\#bm10.

6. Gwida M, Al Dahouk S, Melzer F, Rösler U, Neubauer H, Tomaso H. Brucellosis - regionally emerging zoonotic disease? Croat Med J. 2010;51(4): 289-95. https://doi.org/10.3325/cmj.2010.51.289.

7. Dean AS, Crump L, Greter H, Schelling E, Zinsstag J. Global burden of human brucellosis: a systematic review of disease frequency. PLoS Negl Trop Dis. 2012;6(10):e1865. https://doi.org/10.1371/journal.pntd.0001865.

8. Mcdermott JJ, Grace D, Zinsstag J. Economics of brucellosis impact and control in low-income countries: -EN- -FR- -ES. Rev Sci Tech OIE. 2013;32: 249-61. https://doi.org/10.20506/rst.32.1.2197.

9. Moreno E. Retrospective and prospective perspectives on zoonotic brucellosis. Front Microbiol. 2014;5. https://doi.org/10.3389/fmicb.2014 00213.

10. Radostits OM, Gay CC. Veterinary medicine: a textbook of the diseases of cattle, horses, sheep, pigs and goats. Saunders Elsevier: Edinburgh; 2007.

11. Corbel M. Brucellosis: an Overview. Emerg Infect Dis 1997;3:213-221. doi: https://doi.org/10.3201/eid0302.970219, Brucellosis: an Overview, 2.

12. Pepin M, Russo P, Pardon P. Public health hazards from small ruminant meat products in Europe: -EN- -FR- -ES. Rev Sci Tech OIE. 1997;16:415-25. https://doi.org/10.20506/rst.16.2.1040.

13. Acharya RG, Sapkota S, Sanjyal S, Bhattarai N. Sustainable goat farming for livelihood improvement in South Asia. Bangladesh: SAARC Agriculture Centre; 2017. https://www.sac.org.bd/archives/publications/ Goat\%20Farming.pdf.

14. Rauniyar GP, Upreti CR, Gavigan R, Parker WJ. Constraints to sheep farming in Nepal: development challenge for poverty alleviation. Asian-Australas J Anim Sci. 2000;13(8):1162-72. https://doi.org/10.5713/ajas.2000.1162.

15. Ministry of Agriculture and Livestock Development. Statistical Information On Nepalese Agriculture 2073/74 (2016/17). Government. Nepal; 2017 https://nepalindata.com/resource/statistical-information-nepalese-a griculture-207374-201617/. Accessed 1 Jun 2020.

16. Ministry of Livestock Development. Livestock Statistics Of Nepal. Ministry of Livestock Development; 2017. https://nepalindata.com/resource/livestock-sta tistics-of-nepal-2017\%2D\%2D/.

17. Dipesh Poudel. Goat meat industry in Nepal: opportunities and challenges. 2018. https://biruwa.net/2018/03/goat-meat-industry-nepal-opportunitieschallenges/.

18. Hari Krishna Gautam. Mustang to supply 25,000 sheep and mountain goats for Dashain. My Republica. 2017. https://myrepublica.nagariknetwork.com/ news/27406/.

19. Krishana Prasain. Government faces a goat problem ahead of Dashain. 2020. https://kathmandupost.com/money/2019/09/14/government-faces-a-goatproblem-ahead-of-dashain.
20. The Himalayan. Government sets price for goats, mountain goats. 2019. https://thehimalayantimes.com/business/government-sets-price-for-goatsmountain-goats/.

21. Devleesschauwer B, Ale A, Torgerson P, Praet N, Maertens de Noordhout C, Pandey BD, et al. The Burden of Parasitic Zoonoses in Nepal: A Systematic Review PLoS Negl Trop Dis 2014;8:e2634. doi:https://doi.org/10.1371/journal. pntd.0002634, 1

22. Joshi DD, Maharjan M, Johansen MV, Willingham AL, Sharma M. Improving meat inspection and control in resource-poor communities: the Nepal example. Acta Trop. 2003;87(1):119-27. https://doi.org/10.1016/S0001706X(03)00028-7.

23. Ghimire SC, Egerton JR. Transmission of footrot in migratory sheep and goats of Nepal. Small Rumin Res. 1996;22(3):231-40. https://doi.org/10.1016/ S0921-4488(96)00891-7.

24. Pandeya Y, Joshi D, Dhakal S, Ghimire L, Mahato B, Chaulagain S, Satyal RC, Sah SK, et al. Seroprevalence of brucellosis in different animal species of Kailali district, Nepal. Int J Infect Microbiol. 2013;2(1):22-5. https://doi.org/1 $0.3126 /$ ijim.v2i1.8005

25. Aryal S, Paudel KP. Reproductive disorders and Seroprevalence of brucellosis in yak. Nepal Agric Res J. 2014;8:130-2. https://doi.org/10.312 6/narj.v8i0.11608.

26. Jackson DS, Nydam DV, Altier C. Prevalence and risk factors for brucellosis in domestic yak Bos grunniens and their herders in a transhumant pastoralist system of Dolpo, Nepal. Prev Vet Med. 2014;113(1):47-58. https://doi.org/1 0.1016/j.prevetmed.2013.09.016.

27. Central Animal Quarantie Office, Kathmandu. Animal Quarantine Monthly Report 2018. Nepal; 2018. https://www.caqo.gov.np/uploads/files/54532 50888.pdf.

28. Veterinary Hospital and Livestock Service Center, Rupandehi. Annual Report. Nepal; 2019.

29. Thursfiled M. Veterinary Epidmiology; describing disease Ocurrence. Third. Hoboken: Blackwell Publishing Ltd; 2007.

30. ERGANIS O, HADIMLI HH, SOLMAZ H, CORLU M. Comparison of ROSE Bengal plate test antigens prepared from Brucella Abortus, Brucella Melitensis And Brucella Suis. Bull Vet Inst Pulawy. 2005;49:165-7 https:// www.piwet.pulawy.pl/doc/biuletyn_49-2/04_erganis.pdf.

31. Blasco JM, Marín C, Jiménez de Bagués $M$, Barberán $M$, Hernández A, Molina $\mathrm{L}$, et al. Evaluation of allergic and serological tests for diagnosing Brucella melitensis infection in sheep. J Clin Microbiol. 1994;32(8):1835-40. https:// doi.org/10.1128/JCM.32.8.1835-1840.1994.

32. Getachew T, Getachew G, Sintayehu G, Getenet M, Fasil A. Bayesian estimation of sensitivity and specificity of Rose Bengal, complement fixation, and indirect ELISA tests for the diagnosis of bovine brucellosis in Ethiopia. Vet Med Int. 2016;2016:1-5. https://doi.org/10.1155/2016/8032753.

33. R Studio Team. RStudio: integrated development for R. Boston, MA; 2019.

34. Dahoo I, Martin W, Stryhn H. Veterinary epidemiologic research. 2nd ed., 3. Print. Charlottetown: VER Inc; 2014.

35. Falzon LC, Traoré S, Kallo V, Assamoi J-B, Bonfoh B, Schelling E. Evaluation of the fluorescence polarization assay as a rapid on-spot test for ruminant brucellosis in Côte d'Ivoire. Front Vet Sci. 2019;6:287. https://doi.org/10.3389/ fvets.2019.00287.

36. Turner EL, Dobson JE, Pocock SJ. Categorisation of continuous risk factors in epidemiological publications: a survey of current practice. Epidemiol Perspect Innov. 2010;7(1):9. https://doi.org/10.1186/1742-5573-7-9.

37. Agresti A. Unconditional small-sample confidence intervals for the odds ratio. Biostatistics. 2002;3(3):379-86. https://doi.org/10.1093/biostatistics/3.3.379.

38. Dureh N, Choonpradub C, Tongkumchum P. An alternative method for logistic regression on contingency tables with zero cell counts. Songklanakarin J Sci Technol. 2014;38:171-6 https://rdo.psu.ac.th/sjstweb/ journal/38-2/38-2-8.pdf.

39. Dean AG, Sullivan KM. OpenEpi:open source epidemiologic statistics for public health. USA; 2013. www.OpenEpi.com. Accessed 24 May 2020.

40. Heinze $G$, Schemper M. A solution to the problem of separation in logistic regression. Stat Med. 2002;21(16):2409-19. https://doi.org/10.1002/sim.1047.

41. King G, Zeng L. Logistic Regression in Rare Events Data. P1: FJJ/Shraban. 2001;W006-01:137-63 https://gking.harvard.edu/files/gking/files/Os.pdf.

42. Williams R. Analyzing Rare Events with Logistic Regression. 2019: 1-5. https://www3.nd.edu/ rwilliam/stats3/RareEvents.pdf.

43. Devika S, Jeyaseelan L, Sebastian G. Analysis of sparse data in logistic regression in medical research: a newer approach. J Postgrad Med. 2016; 62(1):26-31. https://doi.org/10.4103/0022-3859.173193. 
44. Rajala EL, Grahn C, Ljung I, Sattorov N, Bogvist S, Magnusson U. Prevalence and risk factors for Brucella seropositivity among sheep and goats in a periurban region of Tajikistan. Trop Anim Health Prod. 2016;48(3):553-8. https:// doi.org/10.1007/s11250-015-0992-3.

45. Hosmer DW, Lemeshow S. Applied logistic regression: Hosmer/applied logistic regression. Hoboken: Wiley; 2000. https://doi.org/10.1002/0471722146.

46. Singh U, Shrestha P, Acharya M, Shrestha S, Khanal D, Joshi B. Seroprevalence of brucellosis during pre-monsoon and post monsoon seasons in different farm animal species of Nepa. Nepalese Vet J. 2016;32(1): 1-6 https://www.nepjol.info/index.php/nvj/issue/archive.

47. Quinn P, Markey B, Leonard F, FitzPatrick E, Fanning S, Hartigan P. Veterinary microbiology and microbial disease. In: Wiley-Blackwell. Second. 2011. p. 334-341.

48. Hirsh DC, Zee YC. Veterinary microbiology. Malden: Blackwell Science; 1999. https://search.ebscohost.com/login.aspx?direct=true\&scope=site\&db= nlebk\&db=nlabk\&AN=51531. Accessed 22 Oct 2020.

49. McDermott JJ, Arimi SM. Brucellosis in sub-Saharan Africa: epidemiology, control and impact. Vet Microbiol. 2002;90(1-4):111-34. https://doi.org/10.1 016/50378-1135(02)00249-3.

\section{Publisher's Note}

Springer Nature remains neutral with regard to jurisdictional claims in published maps and institutional affiliations.

Ready to submit your research? Choose BMC and benefit from:

- fast, convenient online submission

- thorough peer review by experienced researchers in your field

- rapid publication on acceptance

- support for research data, including large and complex data types

- gold Open Access which fosters wider collaboration and increased citations

- maximum visibility for your research: over $100 \mathrm{M}$ website views per year

At $\mathrm{BMC}$, research is always in progress.

Learn more biomedcentral.com/submissions 